\title{
An In-Vitro Assay: Employing Different Management Options for Collar Rot Disease of Sunflower Caused by Sclerotium rolfsii Sacc. Under Coastal Zone of West Bengal, India
}

\author{
Atit Maji ${ }^{*}$, Ranjan Nath ${ }^{2}$ and Abu Taleb ${ }^{1}$ \\ ${ }^{1}$ Murshidabad KrishiVigyan Kendra, Murshidabad, West Bengal University of Animal and \\ Fishery Sciences, West Bengal, India \\ ${ }^{2}$ Department of Plant Protection, Institute of Agriculture, Visva-Bharati, Santiniketan, West \\ Bengal, India \\ *Corresponding author
}

\section{A B S T R A C T}

\section{Keywords}

Bio-agents, Biorational, Fungicides, Sclerotium rolfsii, Management, Coastal zone, West Bengal

Article Info

Accepted:

15 December 2019 Available Online: 20 January 2020
The experiment was conducted to control the Sclerotium rolfsii causing of collar rot disease in sunflower in- vitro condition. Different fungicides, region specific bio-agents and bio-rationals were screened against the pathogen. Among the fungicides Tebuconazole gave significantly (at 5\% level) highest percent inhibition of the growth in all concentrations. Among the seven bio-rationals at $10 \%$ concentration, the maximum per cent inhibition was observed in neem (69.26\%) wherever at $20 \%$ and $30 \%$ concentration the maximum per cent inhibition was observed in cow urine $(80.74 \%)$. In the case of bio agents highest per cent inhibition of the fungal growth was obtained in T. harzianum (90.67\%).

\section{Introduction}

India is one of the leading oilseeds producing countries in the world with $21 \%$ of world's area and $15 \%$ of world's production. Oilseeds also form the second largest agricultural product subsequent to cereals sharing $13 \%$ of the country's gross cropped area and accounts for nearly $5 \%$ of gross national product and $10 \%$ of the value of all agricultural products. Sunflower is scientifically known as
Helianthus annuиs, derived from the name of Greek sun God Helios. It was originally grown as an ornamental plant for its attractive flowers and photosensitive nature. The total area under sunflower in the world is about 25.34 million hectare with the production of 40.04 million tonnes (USDA, 2012). In India, sunflower occupies the fourth place among oilseed crops in terms of acreage and production. The area under sunflower cultivation in India was $0.72 \mathrm{~m}$ ha, with a 
total production of $0.50 \mathrm{~m} \mathrm{t}$ and productivity of $692 \mathrm{~kg} / \mathrm{ha}$ (Anon., 2013). Collar rot in sunflowers by Sclerotiumrolfsii, Mizra and Khokhar (1985).

Sclerotium rolfsii is a soil borne plant pathogen causing root rot, stem rot, collar rot, wilt and foot rot diseases on more than 500 plant species of agricultural and horticultural crops throughout the world (Aycock, 1966). It is one of the most destructive soil inhabiting pathogens so far reported. It has a quite serious status in coastal belt of Sundarbans.

\section{Materials and Methods}

\section{Collection of diseased samples and isolation of the pathogen}

The infected collar parts of sunflower plant were cut into small bits and washed in running water. These bits were surface sterilized with $0.01 \%$ mercuric chloride solution for one minute, were washed thoroughly with sterile distilled water for three times to remove the traces of mercuric chloride if any and then aseptically transferred to Petri-plates containing the sterilized PDA medium.

The plates were incubated at $27 \pm 2^{\circ} \mathrm{C}$ for three days. The fungal growth on fourth day, which arose through the infected tissue was taken by inoculation loop and transferred aseptically to the PDA slants.

\section{Maintenance of culture}

The pure culture of the fungus was obtained by further growing of the culture on the PDA slants and allowed to grow at $27 \pm 2^{\circ} \mathrm{C}$ temperature. The culture thus obtained was stored in refrigerator at $5^{\circ} \mathrm{C}$ for further studies and was sub cultured periodically (15 day interval).

\section{Evaluation of fungicides}

The efficacy of seven fungicides was evaluated against $S$. rolfsii in-vitro by poisoned food technique in three concentrations (viz. $100 \mathrm{ppm}, 150 \mathrm{ppm}$ and $200 \mathrm{ppm})$. Required quantity of individual fungicide was added separately into sterilized molten and cooled potato dextrose agar in conical flask so as to get the desired concentration of the fungicides. Later, $20 \mathrm{ml}$ of the poisoned medium was poured into sterilized Petri plates. Mycelium discs of 5 $\mathrm{mm}$ diameter from five days old pure culture was cut by a sterile cork borer and one such disc was placed at the centre of each agar plate. The plate without any fungicide served as control. Three replications were maintained for each concentration. The plates were incubated at room temperature $\left(27 \pm 2^{\circ} \mathrm{C}\right)$ and the radial growth was measured when fungus attained maximum growth in control plates. The efficacy of the fungicides were expressed as per cent inhibition of mycelial growth over control and calculated by using the formula given by Vincent (1947).

\section{Evaluation of bio rational}

Different bio rational (viz. cow urine, neemAzadirachta indica ,Tulsi -Ocimum tenuiflorum, papaya- Carica papaya , Boganvilla - Boganvilla septabilis, Datura Datura stramonium and Garlic- Allium sativum including control) were evaluated under in-vitro conditions by using poison food technique .

Fresh plant samples were washed in tap water and finally washed thrice using sterilized distilled water. They were crushed in a sterilized pestle and morter by adding a sufficient quantity of sterile distilled water just enough to prepare a $50 \% \mathrm{w} / \mathrm{v}$ standard extract (i.e. stock solution). The extracts were collected by filtering through the two layers 
of muslin cloth. Finally, filterate thus obtained from the leaves were used as stock solution. The stock solution was heated up to $40-50{ }^{\circ} \mathrm{C}$ for 10 minutes to avoid contamination. To avoid contamination and chemical alteration, the extract was stored at $4^{\circ} \mathrm{C}$.

Three different concentrations i.e. $10 \%, 20 \%$ and $30 \% \mathrm{v} / \mathrm{v}$ poisoned media for each treatment (plant extract) were prepared by adding required quantity of stock solution separately into sterilized molten and cooled potato dextrose agar medium in conical flask so as to get the desired concentrations. About $20 \mathrm{ml}$ medium of each concentration was poured into $90 \mathrm{~mm}$ sterilized Petri plates. Three replications were maintained for each treatment

\section{Cow urine collection and preparation}

Fresh cow urine was collected in sterilized vessels from desi cows and was stored in earthen pots. 15 days old cow urine was used for further studies (Sathasivam et al., 2010). A $50 \% \mathrm{v} / \mathrm{v}$ stock solution was prepared by adding sterile water into cow urine. Three different concentrations i.e. $10 \%, 20 \%$ and $30 \% \mathrm{v} / \mathrm{v}$ poisoned media for cow urine treatment were prepared by adding required quantity of stock solution of cow urine separately into sterilized molten and cooled potato dextrose agar medium in conical flask so as to get the desired concentration. The media of different concentrations were autoclaved. About $20 \mathrm{ml}$ medium of each concentration was poured into $90 \mathrm{~mm}$ sterilized Petri plates. Three replications were maintained for each treatment. Suitable control (without any treatment) was maintained.

To study fungicidal efficacy of the biorationals, poisoned food technique was followed (Nene and Thapliyal, 1982). The fungal discs of $5 \mathrm{~mm}$ diameter were taken from actively growing 7 day old pure culture by using cork borer and were transferred aseptically on PDA plates poisoned with different treatments. The inoculated plates were incubated at $27 \pm 1^{0} \mathrm{C}$ till the growth of the colony touched the periphery in control plate. Mean colony diameter for each treatment was recorded. The efficacy of the treatments were expressed as per cent inhibition of mycelial growth over control by using the formula as given by Vincent (1927).

Continuous and injudicious use of chemicals against the disease causing organisms deteriorates the soil health as well as poses environmental hazards. In this situation organic farming has been encouraged in the field of agriculture. Therefore, in the present study, an eco-friendly management option was carried out by using antagonistic bioagents.

\section{Evaluation of region specific bio-control agents}

Isolates of Trichodermasp. and pseudomonas from farmer's field of Kultali block in South 24 Parganas district were screened for their antagonistic ability against the disease collar rot disease of Sunflower caused by Sclerotium rolfsii by dual culture technique.

Twenty ml molten PDA medium was poured into sterile Petri plates and allowed to solidify. Five mm mycelial disc was cut from the margin of the actively growing 8 day old culture of $S$. rolfsii, with a sterile cork borer and placed near the periphery, i.e. one side of the PDA plate and, antagonistic fungus was placed on the other side of the PDA plate just opposite to the pathogen disc.

Similarly, antagonistic bacterium was streaked on one side of the PDA medium in Petri dishes. Simultaneously, one $5 \mathrm{~mm}$ 
mycelial disc of $S$. rolfsii were cut from the margin of the actively growing colony with a sterile cork borer and placed on the opposite sides of the bacterial streak. All the plates were incubated at $27^{\circ} \mathrm{C} \pm 1^{\circ} \mathrm{C}$ for five days. Each treatment replicated five times and appropriate control (without bio control agent) were maintained. The extent of antagonistic activity by fungal and bacterial antagonists was recorded on fifth day by measuring the growth of $S$. rolfsii in dual culture plate and control plate. The per cent inhibition of $S$. rolfsii was calculated as suggested by Vincent (1947).

\section{Results and Discussion}

\section{Evaluation of fungicide against the disease}

Seven different fungicides in three different concentrations (viz. 100ppm, $150 \mathrm{ppm}$ and $200 \mathrm{ppm}$ ) were evaluated with one suitable control.

From the table 1 it was evident that among the seven fungicides with different doses the minimum radial growth was observed in tebuconazole in all three concentrations followed by hezxaconazole, propiconazole and carboxin except in 200ppm where mancozeb showed less radial growth as compared to propiconazole. All the treatments differed among themselves significantly at $5 \%$ level except in between tebuconazole and hexaconazole as well as in between propiconazole and carboxin in $150 \mathrm{ppm}$ concentration.

It is also evident from table 2 that maximum per cent decrease in radial growth was found in tebuconazole followed by hexaconazole, propiconazole and carboxin in all three concentrations except in 200ppm where mancozeb showed more per cent decrease in radial growth as compared to propiconazole. The percent inhibition zone for all treatments were calculated and out of all treatments tebuconazole gave significantly (at 5\% level) highest percent inhibition of the growth in all three concentrations as compared to other treatments and control. The second best inhibition obtained in hexaconazole in all three concentrations followed by propiconazole and mancozeb in 100 and 150 ppm and followed by hexaconazole and mancozeb in 200 ppm. (Table 1)

Chowdary (1997) reported that propiconazole at a concentration of $250 \mathrm{ppm}$ was effective in complete inhibition of $S$. rolfsii. In the present study also propiconazole gave more than $80 \%$ inhibition at all three concentration used.

Chowdhury et al., (1998) found hexaconazole significantly superior to other fungicides even at lower concentration (50 ppm) in checking the growth of $S$. rolfsii. This supported the present finding where hexaconazole gave more than $94 \%$ inhibition at higher concentration (150 and $200 \mathrm{ppm}$ )

Manu et al,. (2012) showed that propiconazole, hexaconazole gave $100 \%$ inhibition zone as compare to the control however, carbendazim and tricyclazole could not show effective inhibitions of Sclerotium rolfsii.

Bhagat and Chakraborty (2013) found mancozeb as least efficient in inhibition of mycelial growth of Sclerotium rolfsii among five different fungicides evaluated in-vitroin the present study also mancozeb did not show efficient inhibition in lower concentration.

It was reported that among eight fungicides tested in vitro against $S$. rolfsii, the maximum $(100 \%)$ inhibition was observed in carboxin, propiconazole, hexaconazole, difenconazole and carbendazim at all three concentrations viz., 500, 1000 and $1500 \mathrm{ppm}$ followed by captan (79.30, 82.76 and 85.23\%) and 
triadimenfon $(49.13,60.23$ and $65.33 \%)$ over control (Begum, et.al., 2014). 100\% inhibition might be due to the higher concentration of different chemicals however, in the present study $100 \%$ inhibition was found in tebuconazole treatment at a concentration of 200ppm.

\section{Evaluation of bio-rationals against the} disease

Seven different biorational in three different concentrations (viz. 10\%, $20 \%$ and 30\%) were evaluated with one suitable control.

From the table 3 it was evident that among the seven bio-rational at $10 \%$ concentration, the minimum radial growth was observed in neem $(27.67 \mathrm{~mm})$ followed by cow urine $(28.67 \mathrm{~mm})$, datura $(29.67 \mathrm{~mm})$ and Tulsi $(30.67 \mathrm{~mm})$. At $20 \%$ concentration the minimum radial growth was observed in cow urine $(17.33 \mathrm{~mm})$ followed by neem $(18.67 \mathrm{~mm})$, tulsi $(21.33 \mathrm{~mm})$ and datura $(23.33 \mathrm{~mm})$. At $30 \%$ concentration the minimum radial growth was observed in cow urine $(0.0 \mathrm{~mm})$ followed by neem $(8.67 \mathrm{~mm})$, tulsi $(13.67 \mathrm{~mm})$ and datura $(17.67 \mathrm{~mm})$. It is also evident from table 3 at lower concentration (10\%) these four biorational did not show significant (at 5\%) difference among themselves. However at highest concentration $(30 \%)$ all treatments differed significantly among themselves.

The percent inhibition zone for all treatments were calculated and from the table $\mathrm{Y}$ it was evident that among the seven bio-rationals at $10 \%$ concentration, the maximum per cent inhibition was observed in neem $(69.26 \%)$ followed by cow urine (68.15\%), datura (67.04\%) and tulsi (65.93\%). At 20\% concentration the maximum per cent inhibition was observed in cow urine $(80.74 \%)$ followed by neem $(79.26 \%)$, tulsi $(76.30 \%)$ and datura (74.07\%). At 30\% concentration the maximum per cent inhibition was observed in cow urine $(100 \%)$ followed by neem $(90.37 \%)$, tulsi $(84.81 \%)$ and datura $(80.37 \%)$ It is also evident from table 4that at highest concentration (30\%) all treatments differed significantly among themselves.

It is also evident from table 5 that maximum per cent decrease in radial growth was found in cow urine followed by neem, tulsi and datura higher concentrations ( $20 \%$ and $30 \%$ ). However, at $10 \%$ concentration highest per cent decrease in radial growth was found in neem followed by cow urine, datura and tulsi.

It was reported that extracts of Allium sativum, Azadirachta indica and Catheranthus roseus [Catharanthus roseus] (all at $10 \%$ concentration) were promising against $S$. rolfsii. It was also reported that steam distillates from leaves of Ocimum gratissimum completely inhibited the radial growth of S. rolfsii(Haralpatil and Raut 2008).

Among eight different plant extracts evaluated in vitro against Sclerotium rolfsii causing dry root rot in chillies, leaf extract of neem (Azadirachta indica) caused maximum inhibition of mycelial growth $(80.74 \%)$ (Madhavi et al., 2011) which also supported the present findings.

Amin et al., (2013) evaluated the effect of different plants extracts and namely rhizome of turmeric, rhizome ginger, neem leaf, tobacco leaf, tobacco leaf extract in water, tobacco leaf extract in cow's urine, and cow's urine at different concentrations $(70 \%, 60 \%$, $50 \%, 40 \%$ and $30 \%$ ) on the growth of Sclerotium rolfsii. They reported thatno growth of the tested fungus was observed in all concentrations of tobacco leaf extract in cow's urine, $70 \%, \quad 60 \%, \quad 50 \%, \quad 40 \%$ concentration of cow's urine alone, and $70 \%$ and $60 \%$ concentration of tobacco leaf 
extracts in water. In the present study even lower concentration (30\%) of cow urine alone showed $100 \%$ growth inhibition of the fungus.

Begum et al., (2014) reported that among different botanicals evaluated against $S$. rolfsii, significantly highest average inhibition was recorded with neem $(74.81 \%)$, followed by tulsi $(67.10 \%)$ at $5 \%$ and $10 \%$ concentrations. In the present study neem and tulsi also showed $69.26 \%$ and $65.93 \%$ inhibition respectively at $10 \%$ concentration.

Pawar et al., (2014) reported that neem (A. indica), turmeric $(C$. longa) and tulsi ( $O$. sanctum) might have some strong toxic principle that directly affects the growth of Sclerotium rolfsii.

Table.1 In-vitro evaluation of different chemicals against the disease on radial growth

\begin{tabular}{|l|l|c|c|c|}
\hline Sl. & Fungicides & \multicolumn{3}{|c|}{ Radial growth in (mm) } \\
\cline { 3 - 5 } & & $100 \mathrm{ppm}$ & $150 \mathrm{ppm}$ & $200 \mathrm{ppm}$ \\
\hline $\mathbf{1}$ & Tebuconazole 25.9\% EC (Folicur) & 4.43 & 3.40 & 0 \\
\hline $\mathbf{2}$ & Hexaconazole 5 \% SC (Contaf Plus) & 12.60 & 5.07 & 4.00 \\
\hline $\mathbf{3}$ & Propiconazole 25 \% EC (Result) & 17.63 & 14.37 & 11.57 \\
\hline $\mathbf{4}$ & Mancozeb 75\% WP (Indofil M-45) & 43.67 & 24.00 & 7.33 \\
\hline $\mathbf{5}$ & Carboxin 75\% WP (Vitavax) & 18.67 & 14.67 & 11.97 \\
\hline $\mathbf{6}$ & Carbendazim50 \% WP (Bavistin) & 89.67 & 87.33 & 72.13 \\
\hline $\mathbf{7}$ & Tricyclozole 75 \%WP (Blastogan) & 77.50 & 75.67 & 65.37 \\
\hline $\mathbf{8}$ & Control & 90.00 & 90.00 & 90.00 \\
\hline & SE $\pm(\mathrm{m})$ & 0.79 & 0.95 & 2.85 \\
\hline & CD (at 5\%) & 2.38 & 2.86 & 8.56 \\
\hline
\end{tabular}

Table.2 In vitro evaluation of different chemicals against the \% decrease in Radial growth

\begin{tabular}{|l|l|c|c|c|}
\hline \multirow{2}{*}{ SI.No. } & \multicolumn{1}{|c|}{ Fungicides } & \multicolumn{3}{|c|}{ \% Decrease in Radial growth } \\
\cline { 3 - 5 } & & $\mathbf{1 0 0} \mathbf{~ p p m}$ & $\mathbf{1 5 0} \mathbf{~ p p m}$ & $\mathbf{2 0 0} \mathbf{~ p p m}$ \\
\hline 1 & Tebuconazole 25.9\% EC & 95.07 & 96.22 & 100 \\
\hline 2 & Hexaconazole 5 \% SC & 86 & 94.37 & 95.56 \\
\hline 3 & Propiconazole 25 \% EC) & 80.41 & 84.03 & 87.15 \\
\hline 4 & Mancozeb 75\% WP & 51.48 & 73.33 & 91.85 \\
\hline 5 & Carboxin 75\% WP & 79.26 & 83.70 & 86.7 \\
\hline 6 & Carbendazim50 \% WP & 0.37 & 2.96 & 19.85 \\
\hline 7 & Tricyclozole 75 \%WP & 13.89 & 15.93 & 27.37 \\
\hline 8 & Control & 0 & 0 & 0 \\
\hline
\end{tabular}


Table.3 In-vitro evaluation of different chemicals against the disease on \% of Inhibition zone

\begin{tabular}{|l|l|c|c|c|}
\hline Sl. & Treatment & \multicolumn{3}{|c|}{ \% of Inhibition zone } \\
\cline { 2 - 5 } No. & & $\mathbf{1 0 0} \mathbf{~ p p m}$ & $\mathbf{1 5 0} \mathbf{~ p p m}$ & $\mathbf{2 0 0} \mathbf{~ p p m}$ \\
\hline $\mathbf{1 .}$ & Tebuconazole 25.9\% EC & $95.07(71.9)^{*}$ & $96.22(62.59)$ & $100.00(71.57)$ \\
\hline $\mathbf{2 .}$ & Hexaconazole 5 \% SC & $86.00(63.82)$ & $94.37(60.86)$ & $95.56(61.95)$ \\
\hline $\mathbf{3 .}$ & Propiconazole 25 \% EC) & $80.41(60.34)$ & $84.04(54.63)$ & $87.15(56.18)$ \\
\hline $\mathbf{4}$ & Mancozeb 75\% WP & $51.48(44.89)$ & $73.33(50.14)$ & $91.85(59.05)$ \\
\hline $\mathbf{5}$ & Carboxin 75\% WP & $79.26(59.46)$ & $83.70(54.45)$ & $86.70(55.96)$ \\
\hline $\mathbf{6}$ & Carbendazim50 \% WP & $5.69(16.46)$ & $9.24(24.78)$ & $27.87(34.24)$ \\
\hline $\mathbf{7}$ & Tricyclozole 75 \%WP & $13.89(23.53)$ & $15.93(28.95)$ & $27.37(34.12)$ \\
\hline $\mathbf{8}$ & Control & $0(0.01)$ & $0(0.01)$ & $0(0.01)$ \\
\hline & SE $\pm(m)$ & 3.36 & 0.57 & 0.88 \\
\hline & CD $($ at 5\%) & 10.06 & 1.72 & 2.64 \\
\hline
\end{tabular}

*Data in parenthesis is angular transformed value

Table.4 In-vitro evaluation of different bio-rational against the disease on radial growth

\begin{tabular}{|l|l|c|c|c|}
\hline Sl. No. & \multirow{2}{*}{ Bio-rationals } & \multicolumn{3}{|c|}{ Radial growth in (mm) } \\
\cline { 3 - 5 } & & $\mathbf{1 0 \%}$ & $\mathbf{2 0 \%}$ & $\mathbf{3 0 \%}$ \\
\hline 1 & Cow urine & 28.67 & 17.33 & 0 \\
\hline 2 & Neem (Azadirachtaindica) & 27.67 & 18.67 & 8.67 \\
\hline 3 & Tulsi ( Ocimumtenuiflorum) & 30.67 & 21.33 & 13.67 \\
\hline 4 & Papaya (Carica papaya) & 80.00 & 72.33 & 42.33 \\
\hline 5 & Bougainvillea (Boganvillaseptabilis) & 69.67 & 41.67 & 34.33 \\
\hline 6 & Datura (Daturastramonium) & 29.67 & 23.33 & 17.67 \\
\hline 7 & Garlic (Allium sativum) & 39.33 & 31.67 & 22.67 \\
\hline 8 & Control & 90 & 90.00 & 90.00 \\
\hline & SE $\pm(m)$ & 1.06 & 0.90 & 0.68 \\
\cline { 2 - 5 } & CD (at 5\%) & 3.18 & 2.69 & 2.03 \\
\hline
\end{tabular}

Table.5 In-vitro evaluation of different bio-rationals against the disease \% Inhibition zone

\begin{tabular}{|l|l|l|l|l|}
\hline \multirow{2}{*}{$\begin{array}{l}\text { Sl. } \\
\text { No. }\end{array}$} & \multicolumn{1}{|c|}{ Bio-rationals } & \multicolumn{3}{c|}{$\%$ Inhibition zone } \\
\hline $\mathbf{1}$ & Cow urine & \multicolumn{1}{c|}{$\mathbf{1 0 \%}$} & \multicolumn{1}{c|}{$\mathbf{2 0 \%}$} & \multicolumn{1}{c|}{$\mathbf{3 0 \%}$} \\
\hline $\mathbf{2}$ & Neem (Azadirachtaindica) & $68.15(55.65)^{*}$ & $80.74(63.97)^{*}$ & $100.00(90)^{*}$ \\
\hline $\mathbf{3}$ & Tulsi (Ocimumtenuiflorum) & $69.26(56.33)$ & $79.26(62.91)$ & $90.37(71.93)$ \\
\hline $\mathbf{4}$ & Papaya (Carica papaya) & $65.93(54.30)$ & $76.30(60.87)$ & $84.81(67.09)$ \\
\hline $\mathbf{5}$ & Bougainvillea (BoganvillaseptabilisL.) & $11.11(19.41)$ & $19.63(26.26)$ & $52.96(46.70)$ \\
\hline $\mathbf{6}$ & Datura (Daturastramonium) & $22.59(28.36)$ & $53.70(47.12)$ & $61.85(51.86)$ \\
\hline $\mathbf{7}$ & Garlic (Allium sativum) & $67.04(54.97)$ & $74.07(59.41)$ & $80.37(63.71)$ \\
\hline $\mathbf{8}$ & Control & $56.30(48.62)$ & $64.81(53.62)$ & $74.81(59.89)$ \\
\hline \multirow{2}{*}{} & SE $\pm(m)$ & 0.79 & $0(0.01)$ & $0(0.01)$ \\
\cline { 2 - 5 } & CD at 5\% & 2.38 & 0.67 & 0.52 \\
\hline
\end{tabular}


Table.6 In-vitro evaluation of different bio-rationals against the disease \% decrease in radial growth over control

\begin{tabular}{|c|c|c|c|c|}
\hline \multirow{2}{*}{$\begin{array}{l}\text { Sl. } \\
\text { No. }\end{array}$} & \multirow[t]{2}{*}{ Bio-rationals } & \multicolumn{3}{|c|}{$\%$ Decrease in Radial growth } \\
\hline & & $10 \%$ & $20 \%$ & $30 \%$ \\
\hline 1 & Cow urine & 68.15 & 80.74 & 100.00 \\
\hline 2 & Neem leaf extract ( Azadirachtaindica) & 69.26 & 79.26 & 91.11 \\
\hline 3 & Tulsi (Ocimumtenuiflorum) & 65.93 & 76.30 & 84.44 \\
\hline 4 & Papaya (Carica papaya) & 11.11 & 19.63 & 52.22 \\
\hline 5 & Bougainvillea (BoganvillaseptabilisL.) & 22.59 & 53.70 & 63.33 \\
\hline 6 & Datura (Daturastramonium) & 67.04 & 74.07 & 82.22 \\
\hline 7 & Garlic (Allium sativum) & 56.30 & 64.81 & 76.67 \\
\hline 8 & Control & 0.00 & 0.00 & 0.00 \\
\hline
\end{tabular}

Table.7 In-vitro evaluation of bio agent against the pathogen

\begin{tabular}{|r|l|c|c|c|}
\hline $\begin{array}{l}\text { Sl. } \\
\text { No. }\end{array}$ & Bio-control agent & $\begin{array}{c}\text { Radial growth in } \\
(\mathbf{m m})\end{array}$ & Inhibition \% & $\begin{array}{c}\text { \% Decrease in } \\
\text { radial growth }\end{array}$ \\
\hline 1 & T. viride & 11.30 & $87.44(74.00)^{*}$ & 87.44 \\
\hline 2 & T. harzianum & 8.40 & $90.67(77.40)$ & 90.67 \\
\hline 3 & P. fluorescence & 65.5 & $27.22(31.22)$ & 27.22 \\
\hline 4 & Control & 90 & $0(0.015)$ & 0 \\
\hline & SE $\pm(m)$ & 0.97 & 1.07 & \\
\hline & CD (at 5\%) & 2.98 & 3.31 & \\
\hline
\end{tabular}

*Data in parenthesis is angular transformed value

\section{Evaluation of bio-agents against the disease}

To formulate an eco friendly management practices against the disease under study the efficacy of different bio agents were evaluated in the present experiment. It is evident from the table 6 that the minimum radial growth was found in $T$. harzianum ( 8.4 $\mathrm{mm}$ ) followed by $T$. viride $(11.30 \mathrm{~mm})$. Both the fungal bio agents were found superior (at $5 \%$ level) to the bacterial one ( $P$. fluorescence) $(65.5 \mathrm{~mm})$ as well as control. However, both the fungal bio agents did not show significant (at 5\% level) difference in between them.

It was also revealed that highest per cent inhibition of the fungal growth was found in
T. harzianum (90.67\%) followed by $T$. viride $(87.44 \%)$ followed by $P$. fluorescence (27.22\%). However, both the fungal bio agents did not show significant (at 5\% level) difference in between them. Per cent decrease in radial growth was found highest in in $T$. harzianum followed by $T$. viride followed by P. fluorescence.

Dutta and Das (2002) observed the among the antagonism $T$. harzianum, $T$. viride and $T$. koningiiagainst tomato isolate of $S$. rolfsii by dual culture technique. Reduced the growth of the pathogen by $61.5,59.1$ and 57.2 per cent, respectively which supported the present study also.

Doley and Jite (2012) observed T. viride 
significant antifungal activities on the sclerotiumrolfsii. $T$. viride significantly inhibited the mycelial radial growth of $S$. rolfsii by $75 \%$.

Manu et al. (2012) showed that in evaluation of antagonistic microorganism T. Harzianum gave best result to control the disease which was at par with the present evaluation.

Conclusion of the study are as follows:

\section{Evaluation of fungicides}

Seven different fungicides in three different concentrations (viz. 100ppm, $150 \mathrm{ppm}$ and $200 \mathrm{ppm}$ ) were evaluated with one suitable control. The percent inhibition zone for all treatments were calculated and out of all treatments tebuconazole gave significantly (at $5 \%$ level) highest percent inhibition of the growth in all three concentrations as compared to other treatments and control. The second best inhibition obtained in hexaconazole in all three concentrations followed by propiconazole and mancozeb in 100 and $150 \mathrm{ppm}$ and followed by hexaconazole and mancozeb in 200 ppm.

\section{Evaluation of bio-rational}

Among the seven bio-rationals at $10 \%$ concentration, the maximum per cent inhibition was observed in neem $(69.26 \%)$ followed by cow urine $(68.15 \%)$, datura $(67.04 \%)$ and tulsi $(65.93 \%)$. At $20 \%$ concentration the maximum per cent inhibition was observed in cow urine $(80.74 \%)$ followed by neem $(79.26 \%)$, tulsi $(76.30 \%)$ and datura (74.07\%). At $30 \%$ concentration the maximum per cent inhibition was observed in cow urine $(100 \%)$ followed by neem $(90.37 \%)$, tulsi $(84.81 \%)$ and datura $(80.37 \%)$.

\section{Evaluation of bio-agents}

Among the bio agents evaluated the highest per cent inhibition of the fungal growth was obtained in $T$. harzianum $(90.67 \%)$ followed by $T$. viride $(87.44 \%)$ followed by $P$. fluorescence $(27.22 \%)$. However, both the fungal bio agents did not show significant (at $5 \%$ level) difference in between them.

\section{References}

Amin, R., Sarker, B. C. Adhikary, S. Sultana K. S. and Zubair T. 2013. Effect of some botanical extracts and cow's urine on sclerotiumrolfsiicausal agent of foot and root rot of betel vine. The International Journal Of Engineering and Science (IJES) 2 :(9) 77-82.

Aycock, R. 1966 Stem rots and other diseases caused by Sclerotium rolfsii North Carolina Agricultural Experiment Station Technical Bulletin No. 174, p. 202

Begum, Amreen, Dadke, M.S., Wagh, S.S., Kuldhar, D.P., Pawar, D.V., Chavan, A.A. and Thaware, D.S. 2014 In-vitro evaluation of fungicides and botanicals against stem rot of chilli caused by Sclerotium rolfsii. Internat. J. Plant Protec., 7(2) : 437-440

Begum, Amreen, Dadke, M.S., Wagh, S.S., Kuldhar, D.P., Pawar, D.V., Chavan, A.A. and Thaware, D.S. 2014 In-vitro evaluation of fungicides and botanicals against stem rot of chilli caused by Sclerotium rolfsii. Internat. J. Plant Protec., 7(2) : 437-440.

Bhagat, I and Chakraborty, B. 2013 Efficacy of Fungicides against Sclerotial Blight of Tea Plant. Our Nature, 11(2):208210.

Chowdary K. A. 1997 Studies on Sclerotial wilt of bell pepper (Capsicum annuumL.). M.Sc.(Ag.) Thesis submitted to Acharya N.G. Ranga Agricultural University, Hyderabad (A.P).

Chowdhury, K.A., Reddy, D.R. and Rao, 
K.C. 1998 Efficiency of systemic (triazoles) and non - systemic fungicides against Sclerotium wilt of bell pepper caused by Sclerotium rolfsi iSacc. Indian Journal of Plant Protection, $26: 125-130$

Doley, K. and Kaur Jite P. 2012In-Vitro Efficacy of Trichoderma viride against Sclerotiumrolfsii and Macrophomina phaseolina Note SciBiol, 4(4):39-44.

Dutta. P. and Das, B. C. 2002 Management of collar rot of tomato by Trichoderma spp. and chemicals. Indian Phytopathology 55: 235-237

Haralpatil S.K. and Raut., S.P. 2008 Efficacy of fungicides, bio-agents and botanicals against collar rot of betel vineJournalof-Plant-Disease-Sciences., 3(1): 93-96

MadhaviBindu, Bhattiprolu G. S.L. and Bali Reddy, V. 2011 Effect of various plant extracts on dry root rot of chillies caused by Sclerotium rolfsii J. Hortl. Sci. 6 (2):156-158 .

Manu, T.G., Nagaraja, A, Chetan, JanawadS. and HosamaniV. 2012. Efficacy of fungicides and biocontrol agents against sclerotium rolfsii causing foot rot disease of finger millet, Under In-vitro conditions G.J. B.A.H.S., 1(2): 46-50

Mizra, S. M. and Khokhar, L. K. 1985. Occurrence of sunflower collar rot diseases caused by Sclerotium rolfsii in Pakistan. Helia8: 41-43.

Nene, Y.L. and Thaplial, P.N. 1982. Fungicides in Plant Disease Control. Oxford and IBH Publishing House, New Delhi, p.163.

Pawar, D. M., Sabalpara, A. N., Prajapati, V. P. and Yadav, P. M. 2014. In-vitro Evaluation of Phytoextracts on the Growth of SclerotiumrolfsiiSacc. causing Foot Rot Disease in Finger Millet Crop. Trends in Biosciences 7(21): 3356- 3358.

Sathasivam A.K, Muthuselvam M, and Rajndran R 2010. Antimicrobial activities of cow urine distillate against some clinical pathogens. Global J. Pharmacol. 4(1):41-44.

USDA. 2012. FAO report on oilseedssunflower for the year 2011-12.

Vincent, J.M. 1927. Distortion of fungal sac hyphae in the presence of certain inhibitors. Nature, 159: 850

\section{How to cite this article:}

Atit Maji, Ranjan Nath and Abu Taleb. 2020. An In-Vitro Assay: Employing Different Management Options for Collar Rot Disease of Sunflower Caused by Sclerotium rolfsii Sacc. Under Coastal Zone of West Bengal, India. Int.J.Curr.Microbiol.App.Sci. 9(01): 1786-1795. doi: https://doi.org/10.20546/ijcmas.2020.901.200 